\title{
Potential of Critical High-technology Metals in Eastern Alpine Base Metal Sulfide Ores
}

\author{
Frank Melcher and Peter Onuk \\ Chair of Geology and Economic Geology, Montanuniversität Leoben, Leoben, Austria \\ Received December 12, 2018; accepted December 17, 2018; published online January 9, 2019
}

\begin{abstract}
The chemical composition of $\mathrm{Zn}-\mathrm{C} \mathrm{Cu}$ and $\mathrm{Fe}$ sulphides in base metal mineralizations of the Eastern Alps was investigated using laser ablation-ICP-MS methods, with a focus on the concentration of high-technology, critical metals. A total of more than 6300 in-situ analyses were carried out on 311 polished sections representing 27 individual mineralizations. These comprise carbonatehosted $\mathrm{Pb}-\mathrm{Zn}$ deposits of the Bleiberg-type, stratiform deposits in Paleozoic metasediments and metavolcanic rocks (e.g. Arzberg, Walchen) and vein-type mineralization (e.g. Koprein, Metnitz). Two sphalerite types emerge: type (1) is poor in $\mathrm{Fe}(<1 \%), \mathrm{Mn}, \mathrm{Co}, \mathrm{Ga}, \mathrm{In}, \mathrm{Sn}, \mathrm{Sb}$, but significantly enriched in Ge (up to $>500 \mathrm{ppm}$ ), $\mathrm{As}, \mathrm{TI}$ and $\mathrm{Pb}$; it is restricted to carbonate-hosted non-metamorphosed sediments. (2) Sphalerite elevated in $\mathrm{Fe}, \mathrm{Co}, \mathrm{Ni}, \mathrm{Cu}, \mathrm{Ag}$, In and $\mathrm{Sn}$ in stratiform and vein-type ores hosted by Paleozoic low to medium grade metamorphic rocks. Large variations exist among both groups, and unusual compositions were also encountered, e.g. vein-type ores showing a Ge-SbCo association at Metnitz, Gurktal nappe. Chalcopyrite associated with type (2) sphalerite may have high Ag and In concentrations. Pyrite and pyrrhotine are carriers of $\mathrm{Co}$, $\mathrm{Ni}$ and As. The highest potential for $\mathrm{Ge}$ is associated with carbonate-hosted ores in the Drauzug and Karawanken Mountains. For Co and In, low potentials are associated with some of the larger stratiform mineralizations.
\end{abstract}

Keywords: High-technology metals, Critical metals, Base metal ore, Eastern Alps

Potenzial für kritische Hochtechnologie-Metalle in ostalpinen Buntmetallsulfidvorkommen

Zusammenfassung: Die chemische Zusammensetzung von $\mathrm{Zn}-, \mathrm{Cu}$ - und Fe-Sulfiden in Buntmetallmineralisationen der

Univ.-Prof. Mag.rer.nat. Dr.mont. F. Melcher ( $\square)$

Chair of Geology and Economic Geology,

Montanuniversität Leoben,

Peter-Tunnerstr. 5,

8700 Leoben, Austria

frank.melcher@unileoben.ac.at
Ostalpen wurde mittels Laser Ablation-ICP-MS untersucht. Der Fokus lag dabei auf kritischen Hochtechnologiemetallen. Insgesamt wurden mehr als 6300 Punktanalysen auf 311 Schliffpräparaten von 27 Erzvorkommen durchgeführt. Diese Vorkommen umfassen karbonatgebundene $\mathrm{Pb}-\mathrm{Zn}$ Mineralisationen vom Bleiberg-Typ, stratiforme Vorkommen in paläozoischen Metasedimenten und Metavulkaniten (z. B. Arzberg, Walchen), sowie gangförmig auftretende Erze (z.B. Koprein, Metnitz). Grundsätzlich können zwei Sphalerit-Typen unterschieden werden: Typ (1) ist arm an Fe $(<1 \%), \mathrm{Mn}, \mathrm{Co}, \mathrm{Ga}, \mathrm{In}, \mathrm{Sn}$ und $\mathrm{Sb}$, aber deutlich an Spurenelementen wie Ge (bis $>500 \mathrm{ppm}$ ), As, TI und $\mathrm{Pb}$ angereichert. Dieser Typ tritt ausschließlich in unmetamorphen mesozoischen karbonatgebundenen Vorkommen auf. Sphalerit Typ (2) ist an $\mathrm{Fe}, \mathrm{Co}, \mathrm{Ni}, \mathrm{Cu}, \mathrm{Ag}$, In und $\mathrm{Sn}$ angereichert und ist auf stratiforme und gangförmige Erzvorkommen in niedrig- bis hochgradig metamorphen Gesteinen beschränkt. Die Variationsbreite in beiden Typen ist sehr groß. Abweichende Zusammensetzungen wurden beispielsweise in den Gangerzen von Metnitz (Gurktal) mit einer Ge-Sb-Co Assoziation angetroffen. Chalkopyrite, die mit Typ (2) Sphalerit vergesellschaftet sind, können erhöhte $\mathrm{Ag}$ und In Konzentrationen führen. Pyrit und Pyrrhotin sind Träger von Co, Ni und As. Karbonatgebundene Erze im Drauzug und den Karawanken weisen das höchste Potenzial für $\mathrm{Ge}$ auf. Geringe Potenziale bestehen für Co und In in einigen stratiformen Erzen.

Schlüsselwörter: Hochtechnologie-Metalle, Kritische Metalle, Buntmetallerz, Ostalpen

\section{Introduction}

Austria is known as a country hosting numerous, albeit small ore deposits [1]. Mining of base metals, including copper, zinc and lead, dates back to the Copper and Bronze ages, at least 5000 years BC, and stopped in the early 1990s due to low metal prices, exhaustion, difficult mining situations and the lack of exploration within the last decades. IRIS, the Interactive Raw Material Informa- 


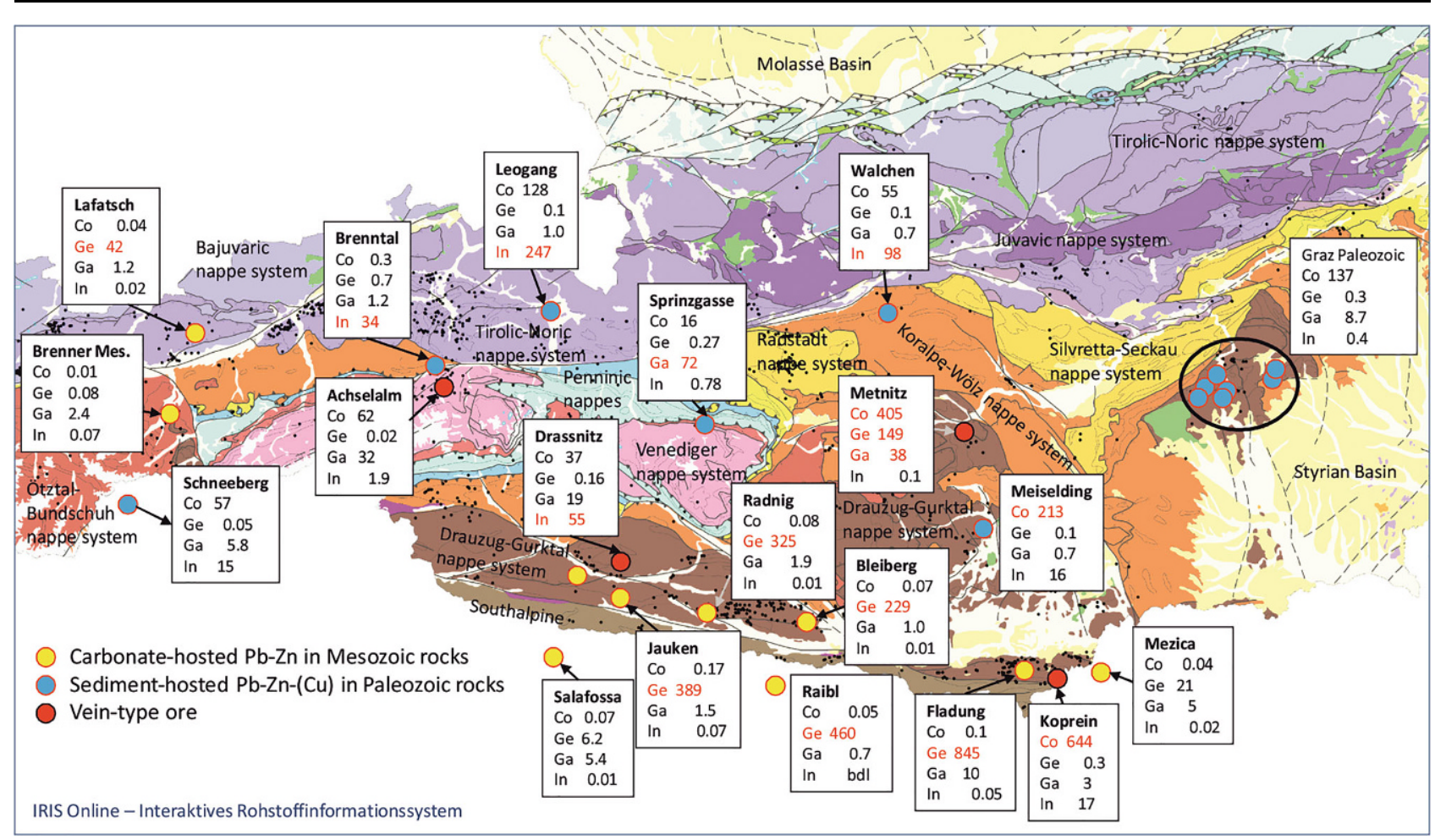

Fig. 1: Tectonic map of central and eastern Austria with sample locations and ore types. The relevant tectonic units are indicated on the map. Base metal mineralizations documented in IRIS are illustrated as black dots. Numbers in boxes are median concentrations of the critical metals Co, Ge, Ga and In in $\mathrm{ppm}(\mu \mathrm{g} / \mathrm{g})$ for each location. Map source: Geologische Bundesanstalt, Wien

tion System maintained by the Geologische Bundesanstalt (GBA), lists 57 "base metal ore districts" with a total of more than 1300 occurrences in Austria (Fig. 1). IRIS represents a compilation of present knowledge but must also be regarded as a contribution to future mineral supply.

The European Union has investigated the future European raw materials demand based on a number of criteria, including supply risks and importance for domestic production. In the 2017 version, 27 raw materials have been classified as "critical" [2]. Due to low, and partly non-existing mining activities related to most of the critical raw materials, there is an urgent need to explore the geological potential of critical raw materials in European countries. In Austria, some of the critical raw materials are currently being produced (graphite, magnesite, tungsten) or were mined in the past (including fluorite, cobalt, antimony and germanium). Base metal ores are known to be potential hosts of some of the critical raw materials. In this paper we focus on germanium ( $\mathrm{Ge}$ ), gallium $(\mathrm{Ga})$, indium (In) and cobalt ( $\mathrm{Co})$. The first data on the concentrations of these elements in Austrian ores dates back to Erich Schroll [3-5], who was among the first worldwide to address the trace element concentrations in ores based on their distribution in various host minerals. Cerny and Schroll [6] investigated the trace element concentrations in concentrate samples from active and dormant mines and presented calculations on the available resources of the critical elements germanium, gallium and indium. They estimated a potential of $76-86$ tons of germanium, 8-10 tons of gallium and 3-4 tons of indium in Austrian base metal ores.
Some of the more valuable trace elements including Co, $\mathrm{Ge}, \mathrm{Ga}, \mathrm{In}, \mathrm{Ag}, \mathrm{Cd}, \mathrm{Tl}$ are incorporated into sphalerite and wurtzite [7]. Galena is a host to Ag, As, Sb, Bi, Tl, Sn and Te. Pyrite may contain elevated concentrations of $\mathrm{Ni}, \mathrm{Co}, \mathrm{As}$ and $\mathrm{Au}$. The data available for Austria are mainly based on spectrometric analysis of single crystals, rock samples or on bulk analysis of concentrates by wet chemical methods. The superior detection limits and good spatial resolution of Laser ablation-ICP-Mass Spectrometry (LA-ICP-MS) render a re-evaluation of Austrian base metal ores possible. The advantages of the method include short measurement times and little sample preparation and thus enable the creation of large data sets. These can then be used to evaluate the variation in element concentration within a sample, an ore type, a deposit or a group of deposits (ore district). As a result, robust statistical data are available. This translates into data for grade and expected variation in a processed mineral concentrate. Provided that reserve/resource data are available, potential tonnages of critical elements may be calculated.

\section{Sampling and Analytical Methods}

The Austrian Mineral Resources Plan [8] has identified areas that should be protected for future mining activities. In total, nine occurrences of base metal ores have been classified as resources worthy of safeguarding, or as resources of provisory worth of safeguarding. These comprise: Lafatsch, Radnig, Pirkach, Metnitz-Vellach, Koprein, Mitter- 


\begin{tabular}{|c|c|c|c|c|c|c|c|c|}
\hline & \multicolumn{2}{|c|}{ Sphalerite } & \multicolumn{2}{|c|}{ Chalcopyrite } & \multicolumn{2}{|c|}{ Pyrite } & \multicolumn{2}{|c|}{ Pyrrhotine } \\
\hline & Md & Range & Md & Range & Md & Range & Md & Range \\
\hline $\mathrm{Fe}$ & 13,500 & $9-221,000$ & \multicolumn{2}{|c|}{ Major element } & \multicolumn{2}{|c|}{ Major element } & \multicolumn{2}{|c|}{ Major element } \\
\hline $\mathrm{Mn}$ & 54 & $<1-11,800$ & 12 & $8-12,100$ & 21 & $13-11,200$ & 25 & $15-18,300$ \\
\hline Co & 39 & $<1-1189$ & 2.6 & $<1-590$ & 115 & $<1-23,300$ & 279 & $3-25,241$ \\
\hline $\mathrm{Ni}$ & 0.3 & $<1-770$ & 1.2 & $<1-1190$ & 75 & $<1-4300$ & 46 & $0.8-1820$ \\
\hline $\mathrm{Ge}$ & 1.1 & $<1-3703$ & 0.4 & $<1-8.2$ & 0.1 & $<1-10$ & 0.1 & $<1-17$ \\
\hline $\mathrm{Ga}$ & 4.3 & $<1-433$ & 0.3 & $<1-41$ & 0.1 & $<1-168$ & 0.1 & $<1-16$ \\
\hline In & 0.15 & $<1-1900$ & 3.7 & $<1-60$ & $<0.1$ & $<1-9$ & $<0.1$ & $<1-4$ \\
\hline $\mathrm{Ag}$ & 4.1 & $<1-4660$ & 97 & $0.8-3220$ & 0.2 & $<1-104$ & 2.3 & $<1-1520$ \\
\hline $\mathrm{Cd}$ & 2093 & $<1-144,000$ & 4.4 & $<1-58$ & 0.1 & $<1-70$ & 0.2 & $<1-128$ \\
\hline As & 2.6 & $<1-20,390$ & 0.2 & $<1-484$ & 105 & $<1-24,970$ & 52 & $<1-11,070$ \\
\hline $\mathrm{TI}$ & 24 & $<1-3314$ & 0.1 & $<1-63$ & $<0.1$ & $<1-1134$ & $<0.1$ & $<1-237$ \\
\hline
\end{tabular}

berg Nord, Schwarleo, Rabenstein, Großstübing. The list does not include mining operations that were closed in the more recent past, such as Bleiberg-Kreuth. Our sampling campaign was structured to cover the most important $\mathrm{Zn}$ $\mathrm{Pb}-(\mathrm{Cu})$ ore districts, including those deposits that are classified as worthy of safeguarding. A total of 356 samples were collected from 27 occurrences (Fig. 1). In addition, samples from collections (Joanneum Graz, Montanuniversität Leoben, Universität Innsbruck, BGR Hannover) were analysed.

Samples were cut using a diamond saw and prepared as polished thick sections of ca. $100 \mu \mathrm{m}$ thickness. These sections were analysed using optical and electron microscopes to identify the overall mineralogical composition, grain size and texture. LA-ICP-MS was used for a number of 23 minor and trace elements in sulphide minerals, employing a New Wave Research Nd:YAG $213 \mathrm{~nm}$ nano second laser ablation system coupled to an Agilent 8800 triple quadrupole ICPMS. For quantification of the element content, the matrixmatched sintered pressed powder pellet reference material (MUL-ZnS 1 [9]) and for quality control, the USGS powder pressed polysulfide reference material MASS-1 [10] were used.

\section{Ore Types}

The base metal occurrences investigated are grouped into three major ore types [11]:

1. Carbonate-hosted lead-zinc deposits are widespread in the Triassic carbonate sequences of the Northern Calcareous and Southern Alps, as well as in Mesozoic cover sequences of the Austroalpine basement units. Ore bodies are strata-bound, occasionally stratiform but usually epigenetic, low-temperature $\left(<200^{\circ} \mathrm{C}\right)$ and relatively small carrying from 3 to $10 \%$ lead and zinc. Common critical trace elements are germanium and gallium, besides cadmium and thallium, and fluorite and barite as a gangue mineral in many occurrences.
2. Sediment-hosted, submarine-exhalative lead-zinc (-copper) deposits ("SEDEX"-type)

Ores consist of pyrite, pyrrhotine, sphalerite, chalcopyrite, galena and a number of minor minerals including (silver-bearing) fahlore and sulphosalts. In the Eastern Alps, SEDEX deposits are known from the Paleozoic of Graz and the Gurktal nappe, both parts of the Austroalpine Paleozoic low-grade metamorphosed basement units. Further stratiform ores of probable SEDEX affinity occur in Austroalpine (e. g., Schneeberg, South Tyrol) and Subpenninic basement complexes (e.g. Brenntal); these ores are often multiply metamorphosed up to amphibolite facies.

3. Vein-type deposits of variable origin and age Vein-type deposits formed during the Eoalpine and $\mathrm{Pa}$ leogene orogenic events [12]. The famous Mitterberger Hauptgang is an example of remobilization of originally stratiform mineralization by later processes. Members of the so-called "Five-element-veins" hosting Bi-Co-Ni$\mathrm{Ag}-\mathrm{U}( \pm \mathrm{As} \pm \mathrm{Sb})$ have been identified in the Alps (e.g. Zinkwand-Vöttern/Schladming); from this genetically complex ore type historical production of critical metals (cobalt) took place in the past. In the present contribution, vein-type ores from Koprein (Karawanken Mountains), Metnitz (Gurktal nappe), Drassnitz (Kreuzeck Mountains) and Achselalm/Flecktrogalm (Tauern Window) were investigated (Fig. 1).

\section{Results}

In total, more than 5300 laser ablation point analyses were carried out on sphalerite grains from 311 polished thin sections, and 1000 point analyses on chalcopyrite, pyrite and pyrrhotite (Table 1). We also included samples from former mining districts in the Eastern Alps that were not part of the detailed study; these include the former mines of Schneeberg, Raibl, Salafossa in Italy, and Mezica (Slovenia). However, sampling was not representative and the numbers generated are unlikely to represent the deposit median and overall variation of trace elements. Results displayed on 


\begin{tabular}{|c|c|c|c|c|c|c|c|c|}
\hline \multirow[t]{2}{*}{ Location } & \multirow[t]{2}{*}{$\begin{array}{l}\text { Tectonic unit (nappe } \\
\text { system) }\end{array}$} & \multirow[t]{2}{*}{ Type } & \multirow{2}{*}{$\begin{array}{l}\text { Co } \\
\text { Md } \\
\end{array}$} & \multirow{2}{*}{$\begin{array}{l}\mathrm{Ge} \\
\mathrm{Md}\end{array}$} & \multirow{2}{*}{$\begin{array}{l}\mathrm{Ga} \\
\mathrm{Md}\end{array}$} & \multirow{2}{*}{$\begin{array}{l}\text { In } \\
\text { Md }\end{array}$} & \multirow{2}{*}{$\begin{array}{l}\text { Original } \\
\text { resource } \\
\text { (estimate) } \\
\text { Tons } \\
\end{array}$} & \multirow{2}{*}{$\begin{array}{l}\text { Resource } \\
\text { potential } \\
\text { Tons }\end{array}$} \\
\hline & & & & & & & & \\
\hline Bleiberg & Drauzug-Gurktal & 1 & 0.07 & 229 & 1.05 & 0.01 & $43 \times 10^{7}$ & $2 \times 10^{6}$ \\
\hline Fladung/Hochobir & Drauzug-Gurktal & 1 & 0.1 & 845 & 10.3 & 0.05 & - & $3 \times 10^{5}$ \\
\hline Jauken & Drauzug-Gurktal & 1 & 0.17 & 389 & 1.5 & 0.07 & - & $5 \times 10^{4}$ \\
\hline Lafatsch & Drauzug-Gurktal & 1 & 0.04 & 42 & 1.2 & 0.02 & $4 \times 10^{6}$ & $6 \times 10^{5}$ \\
\hline Mezica & Drauzug-Gurktal & 1 & 0.04 & 21 & 5 & 0.017 & $34 \times 10^{7}$ & $6 \times 10^{6}$ \\
\hline Radnig & Drauzug-Gurktal & 1 & 0.08 & 325 & 1.9 & $<0.01$ & - & $2.5 \times 10^{5}$ \\
\hline Raibl & Southalpine & 1 & 0.05 & 460 & 0.65 & - & $18 \times 10^{7}$ & - \\
\hline Salafossa & Southalpine & 1 & 0.07 & 6.2 & 5.4 & 0.01 & $10 \times 10^{7}$ & - \\
\hline Seibach & Ötztal-Bundschuh & 1 & 0.01 & 0.08 & 2.4 & 0.07 & - & - \\
\hline Arzberg & $\begin{array}{l}\text { Drauzug-Gurktal (Graz } \\
\text { Paleozoic) }\end{array}$ & 2 & 27 & 0.11 & 2.1 & 4.0 & - & $1.5 \times 10^{6}$ \\
\hline Elisabeth & $\begin{array}{l}\text { Drauzug-Gurktal (Graz } \\
\text { Paleozoic) }\end{array}$ & 2 & 168 & 0.21 & 10.3 & 0.2 & - & \\
\hline Friedrich & $\begin{array}{l}\text { Drauzug-Gurktal (Graz } \\
\text { Paleozoic) }\end{array}$ & 2 & 280 & 0.14 & 20 & 2.2 & - & \\
\hline Guggenbach & $\begin{array}{l}\text { Drauzug-Gurktal (Graz } \\
\text { Paleozoic) }\end{array}$ & 2 & 134 & 0.1 & 7.4 & 0.19 & - & \\
\hline Haufenreith & $\begin{array}{l}\text { Drauzug-Gurktal (Graz } \\
\text { Paleozoic) }\end{array}$ & 2 & 147 & $<0.01$ & 1.5 & 21 & - & \\
\hline Rabenstein & $\begin{array}{l}\text { Drauzug-Gurktal (Graz } \\
\text { Paleozoic) }\end{array}$ & 2 & 28 & 0.06 & 5.6 & 1.0 & - & \\
\hline Silberberg & $\begin{array}{l}\text { Drauzug-Gurktal (Graz } \\
\text { Paleozoic) }\end{array}$ & 2 & 86 & 0.12 & 6.1 & 3.2 & - & \\
\hline Sprinzgasse & Modereck & 2 & 16 & 0.27 & 72 & 0.78 & - & - \\
\hline Brenntal & Venediger & 2 & 0.3 & 0.7 & 1.2 & 34 & $2 \times 10^{5}$ & - \\
\hline Leogang & Tirolian-Noric & 2 & 128 & 0.11 & 1.05 & 247 & $4 \times 10^{5}$ & $1.5 \times 10^{5}$ \\
\hline Meiselding & Drauzug-Gurktal (Murau) & 2 & 213 & 0.13 & 0.67 & 15.6 & - & $10^{5}$ \\
\hline Schneeberg & Koralpe-Wölz & 2 & 57 & 0.05 & 5.8 & 14.3 & $3 \times 10^{6}$ & $1.5 \times 10^{6}$ \\
\hline Walchen & Koralpe-Wölz & 2 & 55 & 0.07 & 1.5 & 98 & - & $4.2 \times 10^{5}$ \\
\hline Achselalm & Venediger & 3 & 57 & 0.02 & 22 & 1.9 & - & - \\
\hline Flecktrogalm & Venediger & 3 & 62 & 0.01 & 32 & 1.5 & - & - \\
\hline Drassnitz & Drauzug-Gurktal & 3 & 37 & 0.16 & 19 & 55 & - & - \\
\hline Koprein & Drauzug-Gurktal & 3 & 644 & 0.29 & 4.1 & 17.1 & - & $10^{5}$ \\
\hline Metnitz & Drauzug-Gurktal (Murau) & 3 & 405 & 149 & 38 & 0.1 & $5 \times 10^{5}$ & $3 \times 10^{5}$ \\
\hline
\end{tabular}

a tectonic map illustrate median concentrations for $\mathrm{Ge}, \mathrm{Ga}$, In and Co (Fig. 1).

Among the sulphides analysed, sphalerite shows the highest concentrations for most trace elements. However, the variation within the dataset is enormous (Table 1). The highest median concentrations of critical elements in a single location are $644 \mathrm{ppm}$ Co (Koprein); $72 \mathrm{ppm} \mathrm{Ga}$ (Sprinzgasse); $846 \mathrm{ppm} \mathrm{Ge} \mathrm{(Fladung/Hochobir);} 247 \mathrm{ppm}$ In (Leogang) (Table 2). Among the genetically associated types, carbonate-hosted ores in Mesozoic rocks have the highest median concentrations of $\mathrm{Ge}, \mathrm{Tl}, \mathrm{As}$ and $\mathrm{Pb}$ at low $\mathrm{Fe}(<1 \mathrm{wt} \%), \mathrm{Co}, \mathrm{Mn}, \mathrm{In}, \mathrm{Ag}, \mathrm{Sn}$ and $\mathrm{Sb}$ (type-1 sphalerite). Stratiform ores hosted in Paleozoic rocks tend to have higher median concentrations of $\mathrm{Fe}, \mathrm{Co}, \mathrm{Cu}, \mathrm{Ni}, \mathrm{Ag}$,
$\mathrm{Sb}, \mathrm{Sn}$ and In, but low Ge and TI (type-2 sphalerite). Veintype ores may have elevated concentrations of all trace elements, most notably of cobalt (Koprein, Metnitz), germanium (Metnitz) and antimony (Metnitz). The variation of critical element concentrations in the three ore types is illustrated in probability diagrams (Fig. 2).

Preliminary analysis of chalcopyrite grains $(N=255)$ reveals elevated concentrations of silver and, in some cases, indium. Highest median values of indium are found in Walchen (ca. $100 \mathrm{ppm}$ ), followed by Guggenbach and Arzberg $(20 \mathrm{ppm})$, while chalcopyrite from Meiselding is highly enriched in silver (556 ppm). Gallium, germanium and cobalt are not of interest. 
Fig. 2: Probability plots for Co, $\mathrm{Ge}, \mathrm{Ga}$ and In concentrations in sphalerite grains of different ore types: BBT, Bleiberg-type; Pal, stratiform base metal sulphides in Paleozoic rocks; Vein, vein-type ores. The data for the Bleiberg deposit (BB) illustrate the variation within a single deposit. Data are in $\mu \mathrm{g} / \mathrm{g}$
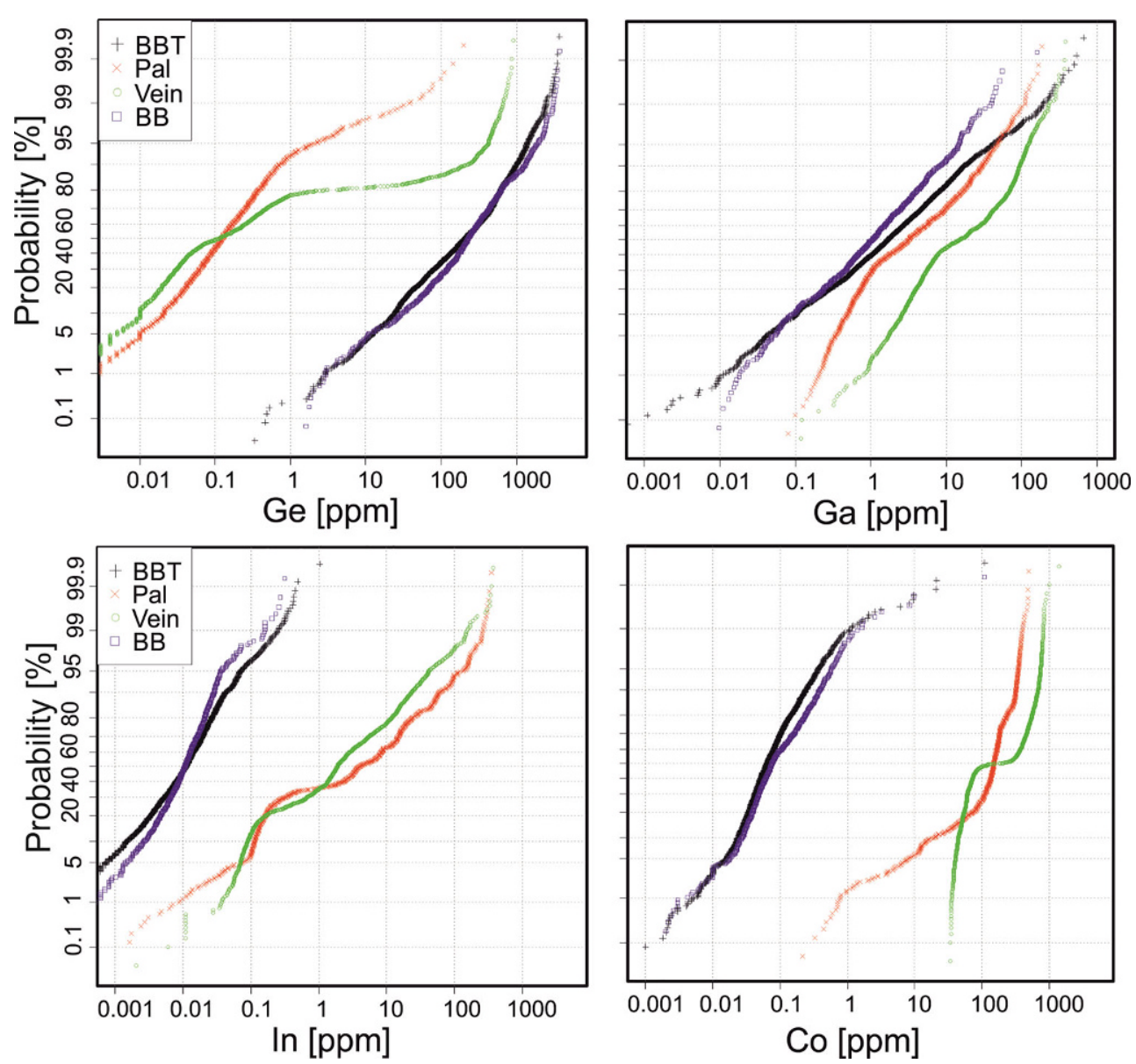

Pyrite $(N=338)$ commonly shows low minor element concentrations except for cobalt, nickel and arsenic. The highest concentration of gold measured is $4.4 \mathrm{ppm}$ (Meiselding). For cobalt and nickel, pyrite from Rabenstein-Deutschfeistritz (1416 and 1204 ppm, respectively) is most prospective.

Pyrrhotite $(N=281)$ reveals minor element variations similar to pyrite, with cobalt, nickel, arsenic, and low concentrations of gallium, germanium, silver and indium. Most promising is Meiselding for cobalt ( $\mathrm{Md}=1574 \mathrm{ppm}$ ) and Metnitz for nickel (595 ppm).

\section{Discussion}

Reliable data on ore grade, distribution of ore minerals, past production and remaining reserves do not exist for base metal mineralizations in the Eastern Alps. Thus, any calculation of potential resources is based on estimates, "best guesses" and literature reviews. The resources estimated from literature data available for the deposits covered in this work add to a total pre-mining resource of 116 million tons of ore containing 7.4 million tons of sphalerite (ca. 5 million tons of $\mathrm{Zn}$ metal); this includes the "big five" Triassic carbonate-hosted $\mathrm{Pb}-\mathrm{Zn}$ deposits of Bleiberg, Mezica, Raibl, Salafossa and Lafatsch (Fig. 1), as well as smaller Mesozoic carbonate-hosted, Paleozoic sediment- hosted and three vein-type deposits. Using median concentrations of trace elements in sphalerite analysed in this study, these deposits had an original resource of about 1420 tons of $\mathrm{Ge}$ in sphalerite, 68 tons of $\mathrm{Co}, 20$ tons of $\mathrm{Ga}, 7$ tons of In, 55 tons of $\mathrm{Ag}, 14,500$ tons of $\mathrm{Cd}$ and 600 tons of $\mathrm{TI}$. Carbonate-hosted $\mathrm{Pb}-\mathrm{Zn}$ deposits of the Bleiberg type account for $94 \%$ of the sphalerite concentrates, $99 \%$ of the $\mathrm{Ge}, 71 \%$ of the $\mathrm{Ga}, 91 \%$ of the $\mathrm{Cd}$ and $100 \%$ of the $\mathrm{Tl}$ originally contained. Stratiform Paleozoic deposits (including the large Schneeberg deposit, South Tyrol) account for $5 \%$ of the concentrates, but $33 \%$ of the Co, $11 \%$ of the $\mathrm{Ga}$, and $94 \%$ of the In contained. Vein-type deposits host only $1.5 \%$ of the sphalerite, but $66 \%$ of the Co, $18 \%$ of the Ga and $4 \%$ of the In contained in sphalerite in the Eastern Alps.

Stratiform deposits in the Graz Paleozoic comprise an estimated ore tonnage of 1.5 million tons and a zinc resource of 90,000 tons. Trace elements in sphalerite are rather low. This study demonstrates that about 150 tons of Co, 0.1 tons of $\mathrm{Ge}, 1.5$ tons of $\mathrm{Ga}, 0.3$ tons of $\mathrm{In}$, and 280 tons of $\mathrm{Cd}$ may be contained in sulphide concentrates. In addition, silver is contained in galena and fahlore.

The remaining resources of the larger $\mathrm{Pb}-\mathrm{Zn}$ mineralizations in the Eastern Alps add up to 6.6 million tons from which about 725,000 tons of zinc concentrate could be recovered. This includes several of those mineralizations that had been evaluated in the 1980s and early 1990s [6] using bulk geochemistry on sphalerite concentrate samples 
(Bleiberg-Kreuth, Radnig, Jauken, Hochobir, Lafatsch, Metnitz, Koprein and the Graz Paleozoic ore district) plus mineralizations for which reserve data could be found in the literature (Meiselding, Walchen, Schneeberg); the large carbonate-hosted deposits of Mezica and Raibl are not included in this calculation. The potential critical high-technology metal contents in sphalerite concentrates from these deposits add up to 78 tons of $\mathrm{Ge}, 4.5$ tons of $\mathrm{Ga}, 5.7$ tons of In and 57 tons of $\mathrm{Co}$, well comparable to the previous estimate [6]. A statistical analysis of the data suggests a variation of 32-160 tons of $\mathrm{Ge}, 2-10$ tons of $\mathrm{Ga}, 3-9$ tons of In and $30-100$ tons of Co within a $50 \%$ probability range around the median concentrations.

Due to the limited dataset presently available, contributions of chalcopyrite and iron sulphides have not been taken into account; however, they will not increase the potential germanium resources. For cobalt, an increased potential is predicted for stratiform deposits in Paleozoic host rocks, e.g. Walchen, Schneeberg, Meiselding, the orebodies in the Graz Paleozoic and Leogang. From bornite-rich ores at Leogang, discrete germanium phases-renierite-have been documented in the past [13]. In general, in the more copper-rich ores, a significant additional indium and silver potential is indicated.

Production of zinc and by-products cadmium and germanium from ore deposits in the eastern and southern Alps was terminated in the 1990s and has never been resumed, although demand and metal prices have significantly increased. This study indicates a potential for zinc and related metals in the Alpine metallogenic province. The original resource of the province was at least $2 \%$ of the currently known global zinc reserves. The production of 174 tons of germanium from zinc ores treated at the Arnoldstein smelter proves the importance of historical production from deposits in the Alps for this critical metal. The overall metal endowment could have been 15-20 times the current global germanium production. The significance of cobalt, gallium and indium hosted by sphalerite is much lower, but due to high prices these metals could constitute important by-products once the production of base metal ores has resumed.

Funding. Open access funding provided by Montanuniversität Leoben.

Open Access This article is distributed under the terms of the Creative Commons Attribution 4.0 International License (http://creativecommons. org/licenses/by/4.0/), which permits unrestricted use, distribution, and reproduction in any medium, provided you give appropriate credit to the original author(s) and the source, provide a link to the Creative Commons license, and indicate if changes were made.

\section{References}

1. Friedrich, G.: Zur Erzlagerstättenkarte der Ostalpen, Radex-Rundschau (1953), Heft 7/8, S. 371-416

2. European Commission: Communication from the Commission to the European Parliament, the Council, the European Economic and Social Committee of the Regions on the 2017 list of Critical Raw Materials for the EU, COM(2017) 490 final, Brussels 13.9.2017, https://eur-lex.europa.eu/legal-content/EN/TXT/?uri=COM:2017:490: FIN (29.11.2018)

3. Schroll, E.: Über das Vorkommen einiger Spurenmetalle in BleiZink-Erzen der ostalpinen Metallprovinz, Tschermaks Mineralogische und Petrographische Mitteilungen (1954), S. 183-208

4. Schroll, E.: Geochemische und geochronologische Daten und Erläuterungen, in: Weber, L. (ed.): Handbuch der Lagerstätten der Erze, Industrieminerale und Energierohstoffe Österreichs, Archiv für Lagerstättenforschung Geologische Bundesanstalt, 19 (1997), S. 395-551

5. Schroll, E.: Blei-Zink-Lagerstätte Bleiberg. Die Geschichte ihrer Erforschung, Carinthia II, 62. Sonderheft, Naturwissenschaftlicher Verein f. Kärnten, 1. Aufl. (2008), S. 1-288 (30. Mai 2008)

6. Cerny, I.; Schroll, E.: Heimische Vorräte an Spezialmetallen (Ga, In, Tl, Ge, Se, Te und $\mathrm{Cd}$ ) in Blei-Zink- und anderen Erzen, Archiv für Lagerstättenforschung Geologische Bundesanstalt, 18 (1995), S. 5-33

7. Cook, N.J.; Ciobanu, C.L.; Pring, A.; Skinner, W.; Shimizu, M.; Danyushevsky, L.; Saini-Eidukat, B.; Melcher, F.: Trace and minor elements in sphalerite: A LA-ICPMS study, Geochimica et Cosmochimica Acta, 73 (2009), S. 4761-4791

8. Weber L, (ed.): Der Österreichische Rohstoffplan, Archiv für Lagerstättenforschung Geologische Bundesanstalt, 26 (2012), S. 1-263

9. Onuk, P.; Melcher, F.; Mertz-Kraus, R.; Gäbler, H.-E.; Goldmann, S.: Development of a matrix-matched sphalerite reference material (MUL-ZnS-1) for calibration of in situ trace element measurements by laser ablation inductively coupled plasma mass spectrometry, Geostandards and Geoanalytical Research, 41 (2017), S. 263-272

10. Wilson, S. A.; Ridley, W. I.; Koenig, A. E.: Development of sulfide calibration standards for the laser ablation inductively-coupled plasma mass spectrometry technique, International Journal of Analytical Atomic Spectrometry, 17 (2002), S. 406-409

11. Melcher, F: Kritische Hochtechnologiemetalle: Verfügbarkeit in der EU mit Fokus auf Österreich, BHM Berg- und Hüttenmännische Monatshefte, 159 (2014), H. 10, S. 406-410

12. Pohl, W.; Belocky, R.: Metamorphism and metallogeny in the Eastern Alps, Mineralium Deposita, 34 (1999), S. 614-629

13. Paar, W. H.; Chen, T.T.: Zur Mineralogie von Cu-Ni (Co)-Pb-Ag$\mathrm{Hg}$ Erzen im Revier Schwarzleo bei Leogang, Salzburg, Österreich, Mitteilungen der Österreichischen Geologischen Gesellschaft, 78 (1986), S. 125-148

14. Baumgarten, B.; Folie, K.; Stedingk, K.: Auf den Spuren der Knappen. Bergbau und Mineralien in Südtirol, Lana: Tappeiner AG Division Verlag, 1. Aufl. 1998 (1. Januar 1998)

15. Unger, H .J.: Der Schwefel- und Kupferkiesbergbau in der Walchen bei Öblarn im Ennstal, Archiv für Lagerstättenforschung in den Ostalpen, 7 (1968), S. 2-52

16. Weber, L. (ed.): Handbuch der Lagerstätten der Erze, Industrieminerale und Energierohstoffe Österreichs, Archiv für Lagerstättenforschung Geologische Bundesanstalt, Vol. 19 (1997), S. 1-607 